\title{
Peningkatan Pengetahuan Perawat Puskesmas tentang HIV/AIDS dengan Metode $A$ Brief Intervention
}

\author{
Increasing Knowledge of Public Health Nurses About HIV/AIDS with \\ A Brief Intervention Method
}

\author{
Ari Athiutama ${ }^{1 *}$, Aldella Trulianty ${ }^{2}$ \\ 1. STIKes 'Aisyiyah Palembang, Indonesia \\ 2. Rumah Sakit Khusus Mata Provinsi Sumatera Selatan, Indonesia \\ *Email Korespondensi: ariathiutama96@gmail.com
}

\begin{abstract}
Abstrak
Latar belakang: Pengetahuan perawat adalah bagian dasar yang diperlukan perawat dalam melaksanakan pelayanan kesehatan dimana pengetahuan yang kurang dapat menimbulkan hal-hal negatif seperti stigma diskriminasi terhadap Orang Dengan HIV/AIDS (ODHA).

Tujuan: Untuk melihat pengaruh dari metode a brief intervention pada pengetahuan perawat puskesmas tentang penyakit HIV/AIDS di Kota Palembang.

Metode: Desain penelitian ini adalah Quasy Experiment Pre-Posttest with Control Group. Pengambilan sampel menggunakan total sampling dengan jumlah sampel sebanyak 48 responden dimana kelompok intervensi dan kelompok kontrol masing-masing berjumlah 24 responden. Analisis data menggunakan Paired Samples T-test dan Independent Samples T-test.

Hasil: Hasil penelitian menunjukkan rata-rata nilai pengetahuan pretest kelompok intervensi sebesar 19.96 meningkat pada posttest sebesar 23.83 dengan nilai $\mathrm{p}$ value 0.001 , sedangkan rata-rata nilai pengetahuan pretest kelompok kontrol sebesar 21.50 meningkat pada posttest sebesar 21.96 dengan nilai $\mathrm{p}$ value 0.302 . Perbedaan antara kelompok intervensi dan kelompok kontrol didapatkan nilai $\mathrm{p}$ value 0.015
\end{abstract}

Kesimpulan: A brief intervention ini efektif terhadap peningkatan pengetahuan perawat puskesmas tentang HIV/AIDS.

Kata kunci: A Brief Intervention; HIV/AIDS; Pengetahuan; Perawat

\begin{abstract}
Background: Nurse's knowledge is the basic part needed by nurses in implementing health services where inadequate knowledge can cause negative things such as stigma of discrimination against people living with HIV/AIDS (PLWHA).

Objective: To see the effect of a brief intervention method on public health nurses knowledge of HIV / AIDS in Palembang.

Method: The research design is the Quasy Experiment Pre-Posttest with Control Group. Sampling using total sampling with a total sample of 48 respondents where the intervention group and the control group each amounted to 24 respondents. Data analysis used Paired Samples T-test and Independent Samples T-test.

Result: The results showed that the mean pre-test knowledge score of the intervention group was 19.96, increasing in the post-test by 23.83 with a p value of 0.001, while the mean pre-test knowledge score of the control group was 21.50, increasing in the posttest by 21.96 with a $p$ value of 0.302 . The difference between the intervention group and the control group was obtained p value 0.015.

Conclusion: This a brief intervention was effective in increasing the knowledge of public health nurses about HIV/AIDS.
\end{abstract}

Keywords: A Brief Intervention; HIV/AIDS; Knowledge; Nurse 


\section{PENDAHULUAN}

Target dari Millennium Development Goals (MDGs) untuk HIV/AIDS (Human Immunodeficiency Virus/ Acquired Immunodeficiency Syndrome) adalah menahan penyebaran dari virus tersebut serta menurunkan angka kejadian kasus baru pada tahun 2015 (1). Indonesia belum mencapai target tersebut yang dibuktikan dengan tidak terkendalinya penyebaran hingga $80 \%$ wilayah kabupaten atau kota di seluruh Indonesia dan setiap tahunnya angka kejadian dari penyakit ini selalu meningkat (2). Kasus baru Orang yang Hidup Dengan HIV/AIDS (ODHA) ditemukan sebanyak 1,7 juta pada tahun 2019 sehingga total kasus mencapai 38 juta kasus dimana hanya 67\% ODHA mengakses antiretroviral (3). Sedangkan di Indonesia angka kejadian HIV cenderung fluktuatif dan puncaknya terjadi pada tahun 2019 yaitu 50.282 kasus (4).

HIV/AIDS yang berkembang pada masyarakat merupakan masalah dengan isu dan perilaku sosial terkait cara penularan, perlindungan dan dukungan dari layanan kesehatan sejak awal ditemukan (5). Penyedia layanan kesehatan merupakan bagian dari masyarakat sehingga persepsi dan sikap mereka dapat dipengaruhi oleh norma, nilai dan sikap masyarakat tersebut, hal ini dikarenakan pengetahuan yang kurang mengenai HIV/AIDS. Pengetahuan terlihat sebagai hal yang utama dengan kejadian yang berhubungan dengan hal-hal negatif terhadap ODHA, pengetahuan dengan informasi yang faktual menangani HIV/AIDS sangat diperlukan untuk meminimalisir hal tersebut (7).

A Brief Intervention merupakan upaya yang bisa dilakukan dalam peningkatan pengetahuan mengenai HIV/AIDS. A Brief Intervention adalah sebuah percakapan pemberian informasi yang sama halnya dengan pemberian informasi dasar pada umumnya namun yang membedakan adalah disampaikan dengan gaya yang memotivasi dan menggunakan beberapa media diantaranya power point, handout, narasumber dan audiovisual. (7). Peneliti telah mewawancara lima orang perawat puskesmas di Kota Palembang, tiga dari lima perawat tersebut memiliki keraguan dalam melakukan perawatan pada ODHA yang diakibatkan karena adanya rasa takut ketika berhadapan dengan ODHA terkait dengan penularan serta menyalahkan kondisi ODHA tersebut. Peneliti juga memberikan kuisioner singkat kepada 10 orang perawat puskesmas tentang pengetahuan didapatkan hasil perawat yang menyatakan HIV dapat menular melalui semua rute penularan (40\%), HIV dapat tertular melalui serangga (80\%), dan HIV tidak menular melalui seks anal (40\%).

\section{METODE}

Penelitian ini telah lolos uji etik pada di Fakultas Kedokteran Universitas Andalas dengan nomor 637/KEP/FK/2019. Peneliti memakai jenis penelitian kuantitatif dengan rancangan Quasi Eksperimen Pre-Posttest with Control Group. Populasi yang dipakai yaitu perawat pada puskesmas yang belum memiliki CST (care support treatment) untuk kelompok intervensi dan perawat pada puskesmas yang telah memiliki CST untuk kelompok kontrol. Total sampling digunakan dalam pemilihan sampel penelitian ini dengan jumlah sampel sebanyak 48 orang perawat yang telah sesuai serta memenuhi kriteria inklusi dan kriteria eksklusi dimana terbagi 24 orang perawat pada kelompok intervensi dan 24 orang perawat pada kelompok kontrol.

Pengumpulan data dengan memakai kuisioner HIV Knowledge Questionnaire (HIV-KQ45) yang diadopsi dari Pasaribu dan telah diuji validitas dengan nilai $r$ hitung $\geq r$ tabel $(0,44)$ serta telah diuji reliabilitas dengan nilai Conbrach Alpha $=0,927$, kuisioner ini bertujuan untuk melihat pengetahuan perawat mengenai HIV/AIDS (8). Data yang telah terkumpul diolah melalui tahap-tahap yaitu editing, coding, entry dan cleaning. Kemudian dilakukan uji normalitas data dan didapatkan hasil bahwa data berdistribusi normal dan memungkinkan analisis data memakai paired samples t-test yang bertujuan untuk mengetahui perbedaan nilai 
antara pretest dan posttest, sedangkan independent samples $t$ test untuk membandingkan nilai kelompok intervensi dan nilai kelompok kontrol. Perlakuan yang peneliti lakukan pada kelompok intervensi adalah a brief intervention yang terdiri dari beberapa media yaitu power point, handout, narasumber dan audiovisual yang masing-masing berisi materi mengenai HIV/AIDS.

Peneliti memberikan perlakuan kepada responden sebanyak dua kali yang diberikan secara luring, sebelumnya responden terlebih dahulu mengisi pernyataan persetujuan untuk disertakan menjadi responden dan diminta untuk bergabung ke dalam grup whatsapp dan selanjutnya responden mengisi soal pretest. Perlakuan pertama dilakukan oleh peneliti dengan media power point dan audiovisual mengenai pengetahuan dasar dari HIV/AIDS dan diakhir dibuka sesi tanya jawab, selanjutnya diberikan handout materi, kemudian pada perlakuan kedua dilakukan oleh tim konselor dan pemegang program HIV/AIDS dengan media narasumber dan audiovisual mengenai pengalaman merawat ODHA, diakhir juga dibuka sesi tanya jawab dan responden diberikan handout materi. Setiap intervensi yang diberikan membutuhkan waktu 60 menit. Kemudian peneliti mengingatkan responden melalui grup whatsapp selama tujuh hari berturut-turut untuk membaca ulang materi ataupun catatan responden sendiri saat perlakuan dan pada hari kedelapan responden diminta mengisi kuisioner posttest.

\section{HASIL}

Tabel 1. Karakteristik Responden

\begin{tabular}{lcccc}
\hline \multirow{2}{*}{ Karakteristik Responden } & \multicolumn{2}{c}{$\begin{array}{c}\text { Kelompok Kontrol } \\
(\mathrm{n}=24)\end{array}$} & \multicolumn{2}{c}{$\begin{array}{c}\text { Kelompok Intervensi } \\
(\mathrm{n}=24)\end{array}$} \\
\cline { 2 - 5 } & $\mathrm{N}$ & $\%$ & $\mathrm{~N}$ & $\%$ \\
\hline Umur & 3 & 12.5 & 4 & 16.7 \\
17-25 Tahun & 4 & 16.7 & 9 & 37.5 \\
26-35 Tahun & 13 & 54.2 & 6 & 25 \\
36-45 Tahun & 4 & 16.7 & 5 & 20.8 \\
46-55 Tahun & 21 & 87.5 & 20 & 83.3 \\
\hline Pendidikan & 3 & 12.5 & 4 & 16.7 \\
1. D3 & & & & \\
2. S1/Profesi & 18 & 75 & 17 & 70.8 \\
Status Nikah & 6 & 25 & 7 & 29.2 \\
1. Menikah & & & & \\
2. Belum Menikah & &
\end{tabular}

Berdasarkan tabel 1 terlihat jumlah responden baik kelompok intervensi maupun kelompok kontrol adalah sama. Karakteristik responden kelompok intervensi lebih banyak berusia 26-35 tahun, berpendidikan D3 dan berstatus menikah. Karakteristik responden pada kelompok kontrol lebih banyak berusia 36-45 tahun, berpendidikan D3 dan berstatus menikah.

Tabel 2. Uji Normalitas Data Pengetahuan Kelompok Intervensi dan Kelompok Kontrol

\begin{tabular}{clccc}
\hline \multicolumn{2}{c}{ Kelompok } & Skewness & SE & Distribusi \\
\hline \multirow{2}{*}{ Intervensi } & Pre & -0.85 & 0.472 & Normal \\
& Post & -0.620 & 0.472 & Normal \\
\hline \multirow{2}{*}{ Kontrol } & Pre & -0.515 & 0.472 & Normal \\
& Post & -0.852 & 0.472 & Normal \\
\hline
\end{tabular}


Berdasarkan tabel 2 terlihat data pengetahuan pretest dan posttest kedua kelompok berdistribusi normal. Pengetahuan pretest pada kelompok intervensi memiliki Skewness -0.85 , sedangkan posttest Skewness -0.620. Pengetahuan pretest pada kelompok kontrol memiliki Skewness -0.515 , sedangkan posttest Skewness -0.852. Hasil tersebut dinyatakan normal karena hasil Skewness dibagi standar error adalah $\leq 2$.

Tabel 3. Pengaruh A Brief Intervention Pada Perawat Puskesmas Terhadap Pengetahuan Tentang HIV/AIDS

\begin{tabular}{lcccc}
\hline Kelompok & Mean & $\Delta$ & SD & P Value \\
\hline Intervensi & & & & \\
Pretest & 19.96 & 3.87 & 3.316 & \multirow{2}{*}{0.001} \\
Posttest & 23.83 & & 3.144 & \\
\hline Kontrol & & & 2.246 & 0.302 \\
Pretest & 21.50 & 0.46 & 1.805 & 0 \\
Posttest & 21.96 & & & \\
\hline
\end{tabular}

Berdasarkan tabel diatas terlihat nilai rata-rata pada kelompok intervensi pretest adalah 19.96 dan nilai rata-rata posttest adalah 23.83 dengan selisih 3.87 , uji statistik menggunakan paired sample $t$ test dengan hasil 0.001 artinya ada pengaruh a brief intervention terhadap pengetahuan perawat puskesmas tentang HIV/AIDS pada kelompok intervensi. Sedangkan nilai rata-rata pada kelompok kontrol pretest adalah 21.50 dan nilai rata-rata posttest adalah 21.96 dengan selisih 0.46 , uji statistik menggunakan paired sample t test dengan hasil 0.302 artinya tidak ada perbedaan pengetahuan perawat puskesmas tentang HIV/AIDS pada kelompok kontrol.

Tabel 4.Perbedaan Rata-rata Pengetahuan Perawat Puskesmas Antara Kelompok Intervensi yang Dilakukan $\boldsymbol{A}$ Brief Intervention dengan Kelompok Kontrol

\begin{tabular}{lccc}
\hline Kelompok & Mean & SD & P Value \\
\hline Intervensi & 23.83 & 3.144 & \multirow{2}{*}{0.015} \\
\hline Kontrol & 21.96 & 1.805 & \\
\hline
\end{tabular}

Berdasarkan tabel 4 dapat dilihat nilai posttest kelompok intervensi adalah 23.83 dan nilai posttest kelompok kontrol adalah 21.96. Maka dapat diartikan adanya perbedaan nilai ratarata pengetahuan posttest dua kelompok tersebut. Uji Statistik menggunakan Independent Samples T-test dengan nilai signifikan 0.015 dan dapat disimpulkan adanya perbedaan nilai pengetahuan posttest perawat antara kelompok intervensi yang diberi a brief intervention dengan kelompok kontrol.

\section{PEMBAHASAN}

Karakteristik responden kelompok intervensi 9 orang (37.5\%) berusia 26-35 tahun (dewasa awal) dan kelompok kontrol 13 orang (54.2\%) berusia 36-45 tahun (dewasa akhir). Terlihat adanya rentang usia perawat yang berbeda antara kelompok intervensi dengan kontrol namun kedua kelompok termasuk pada masa usia dewasa. Usia adalah salah satu hal yang dapat menentukan sikap dari individu, semakin dewasa individu maka akan mudah beradaptasi dalam melakukan interaksi dengan ODHA dan perilaku negatif akan semakin menurun. Masa kerja individu yang lama maka akan semakin banyak juga pengalaman yang dialami. Semakin banyak pengalaman berinteraksi dengan ODHA maka semakin berkurang sikap ragu-ragu perawat. Serupa dengan penelitian Sudarsono yang mengatakan bahwa semakin bertambah usia maka bertambah juga pengalaman dalam bekerja dan usia juga merupakan faktor yang 
dapat menentukan perawat dalam bersikap terhadap pelayanan pada ODHA (9). Karakteristik responden kelompok intervensi 20 orang $(83.3 \%)$ berpendidikan D3 dan kelompok kontrol 21 orang $(87.5 \%)$ berpendidikan D3. Terlihat bahwa baik kelompok intervensi maupun kelompok kontrol didominasi oleh perawat yang berpendidikan D3.

Selain pendidikan formal dan pendidikan nonformal, pengalaman juga merupakan hal yang dapat meningkatkan pengetahuan sehingga dapat memberikan pandangan yang lebih banyak bagi perawat terutama mengenai pengetahuan tentang HIV/AIDS. Hal ini sejalan dengan infodatin perawat dimana jumlah perawat didominasi dengan pendidikan D3 sebanyak 230.262 orang (77.56\%) (10). Menurut hasil penelitian Puteri menunjukkan bahwa banyaknya jumlah perawat yang berpendidikan D3 disebabkan karena motivasi yang kurang untuk melanjutkan pendidikan meliputi usia ( $\mathrm{p}$ value 0.001 ), status pernikahan ( $\mathrm{p}$ value 0.001 ), pendapatan ( $\mathrm{p}$ value 0.001) dan dukungan dari atasan ( $\mathrm{p}$ value 0.001) (11). Penelitian yang dilakukan Boakye \& Mavhandu-Mudzusi menunjukkan bahwa dari total sampel 240 orang perawat yang berinteraksi dengan pasien HIV/AIDS, paling banyak berpendidikan D3 dengan jumlah 100 orang (41.7\%) (12).

Karakteristik responden kelompok intervensi 17 orang $(70.8 \%)$ berstatus menikah dan kelompok kontrol 18 orang $(75 \%)$ berstatus menikah. Baik kelompok intervensi maupun kontrol sama-sama didominasi oleh perawat yang telah menikah. Status perkawinan seorang perawat tidak mengurangi kinerjanya dan juga tidak ada perbedaan dalam melakukan perawatan seperti biasanya baik status telah menikah maupun belum menikah. Sama halnya dengan penelitian yang dilakukan Okpala dkk tentang perawatan pasien HIV/AIDS dimana dari jumlah sampel 240 orang perawat, 59.6\% memiliki status pernikahan sudah menikah (13). Begitu juga penelitian dari Wahyudi dkk mengatakan bahwa status pernikahan baik sudah maupun belum menikah sama saja dalam memberikan pelayanan oleh perawat kepada pasien sesuai dengan kebiasaan dan budaya yang ada (14). Namun, hal tersebut berbeda dengan penelitian yang Baljoon dkk lakukan bahwa status pernikahan yang berbeda akan berdampak pada motivasi serta kinerja petugas kesehatan (15).

Hasil dari analisis data pada kelompok intervensi yaitu nilai rata-rata pretest sebesar 19.96 dan pada nilai posttest menjadi 23.83. Terdapat selisih pengetahuan pada pretest dan posttest yaitu sebesar 3.87. Nilai signifikan yang didapat adalah sebesar 0.001 (nilai $\mathrm{p}$ value $<0,05)$ yang berarti adanya pengaruh a brief intervention terhadap pengetahuan perawat puskesmas tentang HIV/AIDS pada kelompok intervensi. Sedangkan hasil analisis pada kelompok kontrol yaitu nilai rata-rata pretest sebesar 21.50 dan pada nilai posttest menjadi 21.96. Terdapat selisih pengetahuan pretest dan posttest yaitu sebesar 0.46 . Nilai signifikan yang didapat adalah sebesar 0.302 (nilai p value $>0,05$ ) yang berarti tidak adanya perbedaan nilai pengetahuan perawat puskesmas tentang HIV/AIDS pada kelompok kontrol. Beberapa metode dapat digunakan dalam memberikan informasi, beberapa metode yang dilaporkan menunjukkan hasil terjadinya peningkatan pengetahuan perawat mengenai HIV/AIDS. Proses pembelajaran akan menjadi lebih efektif apabila didalamnya melibatkan berbagai metode. Peningkatan rata-rata nilai posttest pengetahuan perawat pada kelompok intervensi terjadi dikarenakan adanya perlakuan a brief intervention yang diberikan oleh peneliti.

Temuan Sieber yang melakukan penelitian mengenai pengetahuan terkait HIV/AIDS pada perawat belum termasuk didalam kategori yang baik akan tetapi masih termasuk kategori yang kurang (16). Sedangkan penelitian yang dilakukan oleh Chen menimbulkan keprihatinan serius tentang pengetahuan dalam memberikan perawatan kepada pasien ODHA dan perlunya peningkatan pendidikan HIV/AIDS untuk perawat dan semua penyedia layanan kesehatan (17). Berdasarkan hal tersebut, untuk dapat menghindari kurangnya pengetahuan dan merubah pengetahuan dari responden mengenai HIV/AIDS, maka peneliti berharap adanya pemberian informasi dengan mengulang kembali materi dasar yang berkaitan dengan 
HIV/AIDS oleh penanggung jawab program HIV/AIDS atau pihak konselor secara terjadwal sehingga pengetahuan dapat meningkat dan sikap negatif terhadap ODHA dapat dicegah. Pemberian intervensi berupa informasi mengenai HIV/AIDS dapat meningkatkan pengetahuan. Penelitian yang dilakukan He menunjukkan hasil setelah dilakukan intervensi dimana pengetahuan terkait HIV/AIDS meningkat secara signifikan ( $\mathrm{p}$ value $=0.000$ ) dan jawaban yang benar meningkat dari $67.9 \%$ menjadi $82.34 \%$ (18). Peningkatan signifikan dalam pengetahuan perawat mengenai HIV/AIDS juga ditemui pada penelitian yang dilakukan oleh Gutierrez dengan jumlah keseluruhan rata-rata tanggapan yang benar pada pretest sebesar 59,3\% dan meningkat pada posttest sebesar 76,4\% (p value $=0,000)(19)$.

Hasil penelitian menunjukkan nilai pengetahuan kelompok intervensi adalah 23.83 dan nilai pengetahuan kelompok kontrol adalah 21.96. Maka dapat diartikan adanya perbedaan nilai dari pengetahuan kelompok intervensi dengan kelompok kontrol. Nilai signifikan 0.015 (nilai $\mathrm{p}$ value $<0,05$ ) dengan demikian dapat disimpulkan adanya perbedaan nilai pengetahuan perawat antara kelompok intervensi yang diberi a brief intervention dengan kelompok kontrol. Hal tersebut membuktikan bahwa responden pada kelompok intervensi memiliki rata-rata pengetahuan yang lebih tinggi dibandingkan nilai rata-rata kelompok kontrol. Selain itu juga terlihat ada perbedaan dalam peningkatan nilai kedua kelompok tersebut, pada kelompok intervensi didapatkan perbedaan nilai rata-rata sebesar 3.87 sedangkan kelompok kontrol didapatkan perbedaan nilai rata-rata sebesar 0.46 . Hal ini juga menunjukkan adanya perbedaan nilai pada kelompok intervensi lebih tinggi dibandingkan dengan perbedaan nilai kelompok kontrol. Dengan adanya peningkatan dan perbedaan nilai pengetahuan, maka peneliti berpendapat bahwa hal tersebut dikarenakan kelompok intervensi diberikan perlakuan a brief intervention berbeda dengan kelompok kontrol yang tidak berikan perlakuan sama sekali. Berdasarkan hal tersebut, terlihat bahwa a brief intervention efektif dan dapat meningkatkan pengetahuan perawat puskesmas mengenai HIV/AIDS.

Pengetahuan merupakan hal yang penting dalam peranan melakukan pencegahan serta perawatan terhadap penderita HIV/AIDS, oleh karena itu pentingnya pengetahuan yang baik dalam memahami penyakit HIV/AIDS tersebut (20). Pengetahuan juga sebagai hal yang utama dengan kejadian yang berhubungan dengan stigma HIV dan diskriminasi terhadap ODHA, pengetahuan dengan informasi yang faktual mengenai HIV/AIDS diperlukan guna mengurangi stigma serta diskriminasi terhadap ODHA didalam masyarakat (6). Pemberian informasi secara faktual dengan metode a brief intervention seperti pada penelitian yang dilakukan Doumas, secara keseluruhan menunjukkan hasil pada peserta yang mengalami kecanduan yaitu terjadi peningkatan pada pengetahuan mereka (nilai p value $<0.05$ ) (21). Hal tersebut sejalan dengan penelitian Hughes yang juga menggunakan a brief intervention dengan topik tentang pendidikan untuk penghentian merokok kepada orang yang dirawat di rumah sakit menunjukkan adanya peningkatan tingkat pengetahuan peserta, nilai mean pretest sebesar 0.94 meningkat pada posttest sebesar 2.77 (p value 0.001) (22). Penelitian a brief intervention juga dilakukan oleh Wojceszek \& Thompson menunjukkan hasil yang sama perubahan yang signifikan pada pengetahuan tentang kesuburan dan infertilitas dimana nilai pengetahuan pretest sebesar 0.64 dan mengalami peningkatan posttest sebesar 4.18 (p value $0.001)(23)$.

Berdasarkan hal diatas, peneliti memberikan pendapat bahwa hasil dari penelitian yang telah dilakukan ini menjadi informasi dasar yang dapat berkontribusi dalam pengembangan profesi keperawatan khususnya keperawatan komunitas. Hasil penelitian ini juga dapat memberi informasi ilmiah bagi para akademisi dan mahasiswa keperawatan untuk menggunakan a brief intervention sebagai metode baru dalam melakukan kegiatan belajar mengajar serta juga kegiatan diluar pendidikan seperti pengabdian masyarakat. 


\section{SIMPULAN}

Hasil dari penelitian ditemukan adanya perbedaan nilai pengetahuan pretest dan posttest pada kelompok intervensi. Hasil uji Independent Samples T-test ditemukan adanya pengaruh $a$ brief intervention terhadap pengetahuan perawat puskesmas pada kelompok intervensi. Dengan demikian dapat disimpulkan bahwa a brief intervention efektif terhadap peningkatan pengetahuan pada perawat puskesmas tentang HIV/AIDS di Kota Palembang.

\section{SARAN}

Disarankan kepada pihak puskesmas melalui dinas kesehatan untuk dapat menjadikan a brief intervention ini sebagai metode inovasi pada upaya promosi kesehatan dan kemudian dimasukkan kedalam usulan rencana kegiatan tahunan sehingga dapat terjadwal secara rutin pemberian informasi mengenai kesehatan khususnya mengenai HIV/AIDS.

\section{UCAPAN TERIMA KASIH}

Peneliti mengucapkan terimakasih kepada Kepala Dinas Kesehatan Kota Palembang, Kepala Puskesmas Dempo, Puskesmas Sukarami, Puskesmas Alang-alang Lebar dan Puskesmas Pakjo.

\section{DAFTAR PUSTAKA}

1. Lisbet. Pencapaian Milenium Development Goals ( MDGs ). Politica. 2013;4(1):129-56.

2. Kemenkes RI. Situasi Penyakit HIV dan AIDS di Indonesia [Internet]. Jakarta Selatan: INFODATIN; $2016 . \quad$ Available from: http://www.depkes.go.id/resources/download/pusdatin/infodatin/infodatin hive aids.pdf

3. UNAIDS. Global Hiv Statistics 2020. End AIDS epidemic [Internet]. 2020;(June):1-3. Available from: https://www.unaids.org/en/resources/fact-sheet

4. Kementerian kesehatan RI. Infodatin HIV AIDS. Kesehatan [Internet]. 2020;1-8. Available from: http://www.depkes.go.id/resources/download/pusdatin/infodatin/Infodatin AIDS.pdf

5. Athiutama A, Murni AW, Tasman. A Brief Intervention Untuk Menurunkan Stigma Diskriminasi Perawat Puskesmas Terhadap Orang Dengan HIV/AIDS. J Keperawatan. 2020;12(1):1-6.

6. Zaki R, Dahlui M, Adekunjo FO, Chinna K, Oche OM, Azahar N, et al. HIV/AIDS Related Stigma and Discrimination against PLWHA in Nigerian Population. PLoS One. 2015;10(12):e0143749.

7. Athiutama A, Murni AW, Tasman T. Meningkatkan Kesediaan Merawat Orang Dengan HIV/AIDS (ODHA) Pada Perawat Puskesmas Dengan Menggunakan Metode A Brief Intervention. NERS J Keperawatan. 2020;16(2):54.

8. Pasaribu MJ. Gambaran Tingkat Pengetahuan dan Sikap Perawat Terhadap Pasien HIV/AIDS di Ruang Rawat Umum Rumah Sakit Dr. H. Marzoeki Mahdi Bogor. 2012;

9. Sudarsono S. Characteristics Associated with Nurses and Midwives Stigma in People with HIV/AIDS (PLWHA) in The District Health Talun Blitar. J Ners dan Kebidanan (Journal Ners Midwifery). 2015;2(1):030-7.

10. Kemenkes RI. Infodatin Perawat 2017.Pdf [Internet]. 2017. p. 1-12. Available from: http://www.depkes.go.id/resources/download/pusdatin/infodatin/infodatin perawat 2017.pdf

11. Puteri AD. Analisis Faktor Yang Berhubungan Dengan Motivasi Perawat Di Rumah Sakit Umum Daerah Teluk Kuantan Tahun 2016. In: Prepotif Jurnal Kesehatan Masyarakat. 2017. p. 13-21. 
12. Boakye DS, Mavhandu-Mudzusi AH. Nurses knowledge, attitudes and practices towards patients with HIV and AIDS in Kumasi, Ghana. Int J Africa Nurs Sci [Internet]. 2019;11(May):100147. Available from: https://doi.org/10.1016/j.ijans.2019.05.001

13. Okpala PU, Uwak R, Nwaneri AC, Onyiapat J, Emesowum A, Osuala EO, et al. Nurses' knowledge and attitude to the care of HIV/AIDS patients in South East, Nigeria. Int J Community Med Public Heal. 2017;4(2):547.

14. Wahyudi, Sutria E, Ashar MU, Syisnawati. Faktor-Faktor yang Berhubungan dengan Perilaku Caring Perawat di Ruang Perawatan Interna. J Islam Nurs. 2017;2(2):82-92.

15. Baljoon R, Banjar H, Banakhar M. Nurses' Work Motivation and the Factors Affecting It: A Scoping Review. Int J Nurs Clin Pract. 2018;5(1).

16. Siebers R. Nurses ' knowledge of HIV/AIDS. Interbational J Community Med Public Heal. 2017;4(8):6040.

17. Chen, W., Han, W. Holzemer W. Transmission in Northeastern China. NIH Public Access. 2013;18(7):417-22.

18. He L, Lu Z, Huang J, Zhou Y, Huang J, Bi Y, et al. An integrated intervention for increasing clinical nurses' knowledge of HIV/aids-related occupational safety. Int $\mathrm{J}$ Environ Res Public Health. 2016;13(11).

19. Gutierrez JM. Assessment of HIV/AIDS educational intervention on stigma reduction among nurses: a quasi-experimental study. Int J Adv Nurs Stud. 2014;3(2):90-6.

20. Vidiyanti PD. Pengetahuan Dan Sikap Remaja Dalam Upaya Pencegahan HIV/AIDS ( Teenage Knowledge and Attitude to Prevent HIV / AIDS ). 2015;2(1):60-6.

21. Doumas DM, Esp S, Miller R. Impact of Brief Intervention Workshops on Addiction Provider Knowledge, Skills, Negative Attitudes, and Interest in Implementing EvidenceBased Practices. J Drug Educ. 2017;47(3-4):121-37.

22. Hughes J, Smith LS, Garrett-Wright D. Brief Intervention on Nurses' Knowledge and Behavior Regarding Smoking Cessation. J Nurses Prof Dev. 2018;34(5):257-62.

23. Wojcieszek AM, Thompson R. Conceiving of change: A brief intervention increases young adults' knowledge of fertility and the effectiveness of in vitro fertilization. Fertil Steril [Internet]. 2013;100(2):523-9. Available from: http://dx.doi.org/10.1016/j.fertnstert.2013.03.050 